\title{
Clearing and Labeling Techniques for Large-Scale Biological Tissues
}

\author{
Jinyoung Seo ${ }^{1,5}$, Minjin Choe ${ }^{2,5}$, and Sung-Yon $\mathrm{Kim}^{1,2,3,4 *}$
}

\begin{abstract}
Clearing and labeling techniques for large-scale biological tissues enable simultaneous extraction of molecular and structural information with minimal disassembly of the sample, facilitating the integration of molecular, cellular and systems biology across different scales. Recent years have witnessed an explosive increase in the number of such methods and their applications, reflecting heightened interest in organ-wide clearing and labeling across many fields of biology and medicine. In this review, we provide an overview and comparison of existing clearing and labeling techniques and discuss challenges and opportunities in the investigations of large-scale biological systems.
\end{abstract}

${ }^{1}$ Department of Chemistry, ${ }^{2}$ Department of Biophysics and Chemical Biology, ${ }^{3}$ School of Biological Sciences, ${ }^{4}$ Institute of Molecular Biology and Genetics, Seoul National University, Seoul 08826, Korea, ${ }^{5}$ These authors contributed equally to this work.

${ }^{*}$ Correspondence: sungyonkim@snu.ac.kr

Received 5 April, 2016; revised 2 May, 2016; accepted 3 May, 2016; published online 30 May, 2016

Keywords: 3D volume imaging, CLARITY, large-scale tissue clearing, stochastic electrotransport, SWITCH, whole-mount labeling

Abbreviations: Ab, Antibody; ACT-PRESTO, Active Clarity Technique-Pressure Related Efficient and Stable Transfer of macromolecules into Organs; A4P0, 4\% Acrylamide; A4P4B0.05, 4\% Acrylamide- $4 \%$ PFA- $0.05 \%$ Bis-Acrylamide; BABB, Benzyl Alcohol-Benzyl Benzoate; CLARITY, Clear Lipid-exchanged Acrylamide-hybridized Rigid Imaging/Immunostaining/In situ hybridization-compatible Tissue-hYdrogel; COLM, Clarity Optimized Light-sheet Microscopy; CUBIC, Clear, Unobstructed Brain/Body Imaging Cocktails and Computational analysis; DBE, Dibenzyl Ether; DCM, Dichloromethane; EDC, 1-Ethyl-3-(3-dimethylaminopropyl)carbodiimide; FP, Fluorescent Protein; GA, Glutaraldehyde; G1P4, 1\% Glutaraldehyde-4\% PFA; iDISCO, Immunolabeling-enabled 3D Imaging of Solvent-Cleared Organs; ISH, In Situ Hybridization; LSM, Light Sheet Microscopy; PACT, Passive CLARITY Technique; PARS, Perfusion-assisted Agent Release in Situ; PEG, Polyethylene Glycol; PFA, Paraformaldehyde; RI, Refractive Index; RIMS, Refractive Index Matching Solution; SDS, Sodium Dodecyl Sulfate; SECLARITY, Stochastic Electrotransport CLARITY; smFISH, Single Molecule Fluorescent In Situ Hybridization; SPED, SPherical aberration assisted Extended depth-of-field; SWITCH, System-Wide control of Interaction Time and kinetics of CHemicals; THF, Tetrahydrofuran; TX-100, Triton X-100; 3DISCO, 3D Imaging of SolventCleared Organs

\section{INTRODUCTION}

Biological tissues are stunningly complex, with each gram consisting of hundreds of millions of cells. Each cell can be classified into numerous genetically and functionally distinct cell types, and even within the same category, individual cells often show clear heterogeneity. In studying such a complex system, obtaining and correlating compositional (molecular) and threedimensional (3D) spatial (structural and morphological) information across different length scales are of paramount importance. Most existing techniques, however, allow the investigation of only a small portion of the tissue at high resolution or a large area at low resolution. For example, typical histological techniques with fluorescence microscopy can yield clear images of subcellular structures only from micron-thick sections (Hofman and Taylor, 2001); in contrast, existing large-scale 3D imaging techniques such as magnetic resonance imaging are limited in the spatial resolution and the molecular information they can provide (Huang et al., 1991; Muehllehner and Karp, 2006; Reiser et al., 2007; Van Essen et al., 2013). This challenge has been impeding both basic and clinical investigations of large tissues.

Increasing numbers of emerging clearing and labeling techniques for large-scale tissues enable the extraction of detailed 3D structural and molecular information across the millimeterto-centimeter scale at sub-micron resolution (Fig. 1) (Dodt et al., 2007; Kim et al., 2013; Richardson and Lichtman, 2015; Susaki and Ueda, 2016). In turn, the rising interest in the study of large intact tissues in $3 \mathrm{D}$ is driving the development of many novel techniques from multiple laboratories. Here we review the existing clearing and labeling techniques for biological tissues, placing particular emphasis on the basic principles underlying each method. We also highlight challenges and opportunities in the development of future tissue processing techniques.

\section{CLEARING TECHNIQUES FOR LARGE-SCALE TISSUES}

The first tissue clearing technique dates back to 1910, when the German anatomist Walter Spalteholz developed an organic solution (a mixture of benzyl alcohol and methyl salicylate) to clear large tissues (Spalteholz, 1914). This pioneering work was revisited a century later when 3D fluorescence volume imaging gained in popularity (Dodt et al., 2007; McGurk et al., 2007), leading to the development of various clearing methods with distinct principles. We classified the contemporary methods into three categories according to their main mode of action: (1) simple refractive index (RI)-matching, (2) delipidation combined with dehydration (solvent-based) or hyperhydration 
A
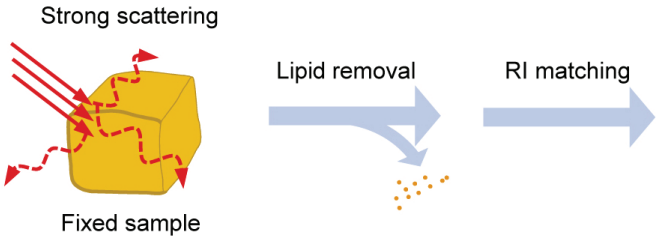

Less scattering

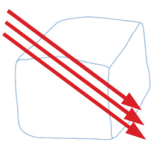

Cleared sample

B Simple RI matching
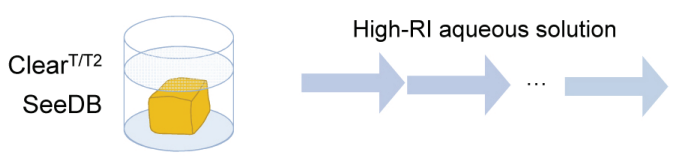

(weak clearing)

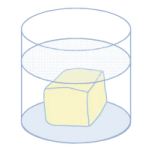

C Delipidation and dehydration/hyperhydration followed by RI matching

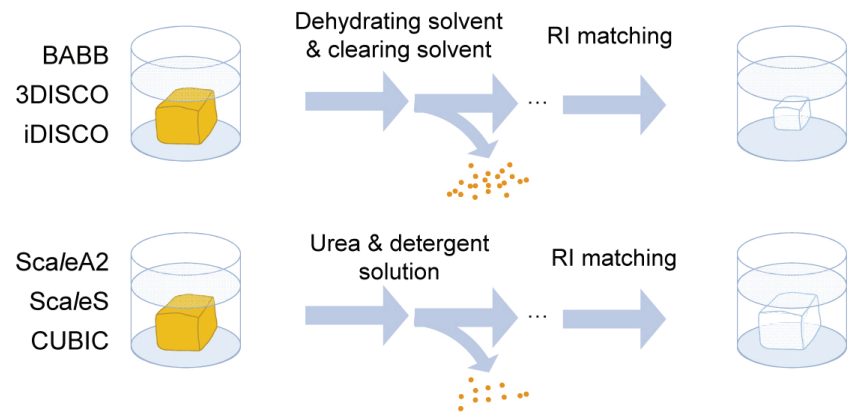

D Tissue-gel hybrid formation followed by delipidation and RI matching

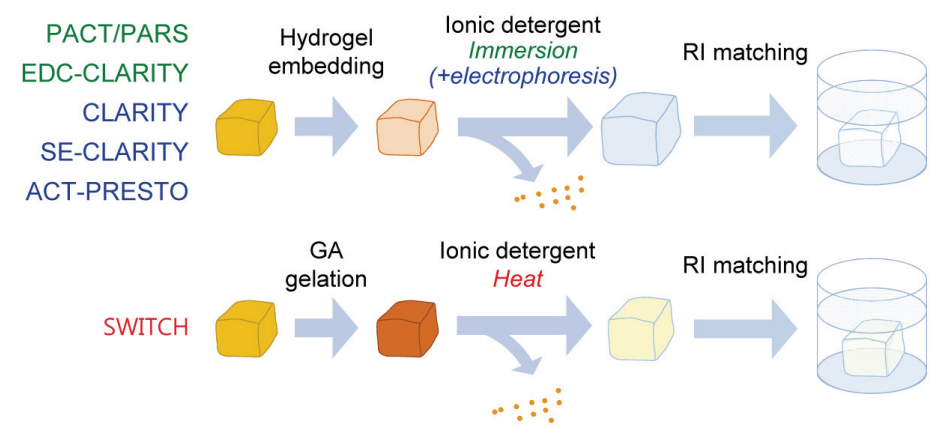

Fig. 1. Tissue clearing techniques. (A) Light scattering in biological tissues can be reduced by removal of lipid and RI matching. (B) Simple immersion in a high-RI aqueous solution renders the tissue modestly transparent by homogenizing scattering throughout the sample. (C) Delipidation and dehydration/hyperhydration followed by refractive index matching. (Top) For solvent-based clearing, the tissue is incubated in dehydrating solvent for delipidation and dehydration, and is moved to a high-RI clearing solvent where RI matching and additional delipidation occur. (Bottom) The sample is placed in an aqueous solution that contains high concentration of non-ionic detergent and denaturant, where delipidation, hyperhydration, and RI matching take place. (D) A biological sample is first transformed into a tissue-gel hybrid by hydrogel embedding (Top) or glutaraldehyde fixation (Bottom), where the gel network increases the tissue integrity. The tissue-gel hybrid then can withstand extensive delipidation by incubation in ionic detergent (SDS) assisted by electrophoresis or heating. (aqueous-based) followed by RI matching, and (3) tissue-gel hybridization followed by delipidation and RI matching (Table 1).

\section{SIMPLE REFRACTIVE INDEX MATCHING}

Matching the $\mathrm{RI}$ of a tissue to that of the medium reduces light scattering, the principal cause of tissue opaqueness. A tissue is a composite of biomolecules with different Rls (protein, $\mathrm{RI}$ 1.43; lipids, RI 1.44; water, RI 1.33), which collectively constitute the overall tissue RI of 1.4-1.5 (Bolin et al., 1989; Tuchin, 2015). Thus, simple incubation of tissues in the highconcentration solutions of formamide (ClearT, RI 1.44), formamide and polyethylene glycol (PEG) (ClearT2, RI 1.44) or fructose with $\alpha$-thioglycerol (SeeDB, RI 1.49) can replace water and render the tissues modestly transparent (Ke et al., 2013; Kuwajima et al., 2013; Richardson and Lichtman, 2015). These methods exhibit weak-to-moderate clearing capabilities, but are easy to implement, reversible and economic. Each method retains different degrees of fluorescent signals: Clear $^{\top}$ mostly quenches the signal from fluorescent proteins (FPs) as formamide disrupts the fluorophore, Clear $^{T 2}$ better preserves fluorescence by stabilizing proteins with PEG, and SeeDB well retains fluorescence as fructose does not disrupt FPs (Ke et al., 2013; Kuwajima et al., 2013). Most molecular probes do not penetrate well into the tissues processed with these techniques; their uses are mostly limited to the samples that are labeled in advance. These methods do not involve delipidation and preserve lipophilic dyes (e.g. Dil), which can be useful for tracing neurons in post-fixed tissues where genetic labeling is impossible.

While the concept of refractive index matching has been used to explain the clearing effect, it does not fully explain some empirical observations. For example, in human and porcine skin samples, no correlation between RI and clearing effect was observed (Choi et al., 2005; Mao et al., 2008); instead, the clearing potential (of alcohols) was related to the number of 
Table 1. Comparison of tissue clearing methods. General properties and performances of major published clearing methods. The methods are categorized according to the main mode of action: RI matching by simple immersion, organic solvent-based clearing (dehydration, delipidation, RI matching), aqueous solution-based clearing (hyperhdyration, delipidation, RI matching), and tissue-gel hybridization.

\begin{tabular}{|c|c|c|c|c|c|c|c|c|c|c|c|c|c|c|}
\hline \multirow{2}{*}{$\begin{array}{l}\text { Tech- } \\
\text { nique }\end{array}$} & \multicolumn{3}{|c|}{ Reagents } & \multicolumn{7}{|c|}{ Clearing properties } & \multicolumn{3}{|c|}{ Labeling properties } & \multirow[b]{2}{*}{ Reference } \\
\hline & $\begin{array}{l}\text { Main clearing } \\
\text { reagent }\end{array}$ & Detergent & Gel & $\begin{array}{c}\text { Final } \\
\text { Rl }\end{array}$ & $\begin{array}{l}\text { Clearing } \\
\text { capability }\end{array}$ & Tissue scale ${ }^{a}$ & $\begin{array}{c}\text { Clearing } \\
\text { time }^{\mathrm{b}}\end{array}$ & FP signal ${ }^{c}$ & $\begin{array}{c}\text { Lipid } \\
\text { preserved }\end{array}$ & $\begin{array}{l}\text { Tissue } \\
\text { integrity }\end{array}$ & $\mathrm{IHC}^{\mathrm{e}}$ & RNA & $\begin{array}{l}\# A b \\
\text { tested }\end{array}$ & \\
\hline \multicolumn{15}{|c|}{ RI matching by simple immersion: aqueous-based clearing } \\
\hline Clear $^{\top}$ & $\begin{array}{c}95 \% \\
\text { formamide }\end{array}$ & - & - & 1.44 & Medium & $\begin{array}{l}\text { Young adult } \\
\text { mouse brain }\end{array}$ & 2-3 days & - & + & \multirow{3}{*}{ No change } & $\begin{array}{c}\text { Yes } \\
\text { (small) }\end{array}$ & - & - & $\begin{array}{l}\text { Kuwajima } \\
\text { et al., } 2013\end{array}$ \\
\hline Clear $^{\mathrm{T} 2}$ & $\begin{array}{c}50 \% \\
\text { formamide, } \\
20 \% \text { PEG }\end{array}$ & - & - & 1.44 & Medium & $\begin{array}{l}\text { Young adult } \\
\text { mouse brain }\end{array}$ & 2-3 days & ++ & + & & $\begin{array}{l}\text { Yes } \\
\text { (small) }\end{array}$ & - & 2 & $\begin{array}{l}\text { Kuwajima } \\
\text { et al., } 2013\end{array}$ \\
\hline SeeDB & $\begin{array}{c}80.2 \% \\
\text { fructose, } \\
0.5 \% \text { thio- } \\
\text { glycerol }\end{array}$ & - & - & 1.48 & Weak & $\begin{array}{l}\text { Young adult } \\
\text { mouse brain }\end{array}$ & $\begin{array}{l}\text { Several } \\
\text { days }\end{array}$ & ++ & ++ & & $\begin{array}{l}\text { Yes } \\
\text { (small) }\end{array}$ & - & 1 & $\begin{array}{l}\text { Ke et al., } \\
2013\end{array}$ \\
\hline \multicolumn{15}{|c|}{ Dehydration, delipidation and RI matching: solvent-based clearing } \\
\hline BABB & BABB & - & - & 1.55 & Strong & $\begin{array}{c}\text { Adult mouse } \\
\text { brain }\end{array}$ & 2-3 days & $\stackrel{+}{\stackrel{+}{\text { (half day) }}}$ & - & \multirow{3}{*}{$\begin{array}{c}\text { Shrinkage; } \\
\text { hard and } \\
\text { brittle }\end{array}$} & $\begin{array}{c}\text { Yes } \\
\text { (small) }\end{array}$ & - & - & $\begin{array}{l}\text { Dodt et al., } \\
2007\end{array}$ \\
\hline 3DISCO & DBE, DCM & - & - & 1.56 & $\begin{array}{l}\text { Very } \\
\text { strong }\end{array}$ & $\begin{array}{l}\text { Young adult } \\
\text { mouse brain }\end{array}$ & $1-3$ days & $\stackrel{+}{(1-2 \text { days })}$ & - & & $\begin{array}{c}\text { Yes } \\
\text { (limited) }\end{array}$ & - & - & $\begin{array}{c}\text { Ertürk et } \\
\text { al., 2012a; } \\
2012 \mathrm{~b}\end{array}$ \\
\hline iDISCO & DBE, DCM & - & - & 1.56 & $\begin{array}{l}\text { Very } \\
\text { strong }\end{array}$ & $\begin{array}{c}\text { Adult mouse } \\
\text { brain }\end{array}$ & 1-3 days & $\stackrel{+}{(2-4 \text { days })}$ & - & & $\begin{array}{c}\text { Yes } \\
\text { (large) }\end{array}$ & - & 28 & $\begin{array}{l}\text { Renier et } \\
\text { al., 2014 } \\
\end{array}$ \\
\hline \multicolumn{15}{|c|}{ Hyperhydration, delipidation and RI matching: aqueous-based clearing } \\
\hline ScaleA2 & $\begin{array}{l}\text { 4M urea, } \\
10 \% \text { glycerol }\end{array}$ & $\begin{array}{c}0.1 \% \mathrm{TX}- \\
100\end{array}$ & - & 1.38 & Medium & $\begin{array}{l}\text { Adult mouse } \\
\text { brain }\end{array}$ & 2 weeks & ++ & - & $\begin{array}{l}\text { Expansion; } \\
\text { soft and } \\
\text { fragile }\end{array}$ & No & - & - & $\begin{array}{l}\text { Hama et } \\
\text { al., 2011 }\end{array}$ \\
\hline Scales & $\begin{array}{l}\text { 4M urea, } \\
\text { sorbitol }\end{array}$ & $\begin{array}{c}0.2 \% \text { TX- } \\
100\end{array}$ & - & 1.44 & Strong & $\begin{array}{l}\text { Old mouse } \\
\text { brain }\end{array}$ & $\begin{array}{l}\text { Several } \\
\text { days }\end{array}$ & ++ & + & $\begin{array}{l}\text { No change; } \\
\text { firm and } \\
\text { sectionable }\end{array}$ & $\begin{array}{c}\text { Yes } \\
\text { (limited }^{\mathrm{e}} \text { ) }\end{array}$ & - & 5 & $\begin{array}{l}\text { Hama et } \\
\text { al., 2015 }\end{array}$ \\
\hline CUBIC & $\begin{array}{l}\text { 4M urea, } \\
\text { aminoalco- } \\
\text { hols }\end{array}$ & $\begin{array}{c}15 \% \text { or } \\
0.1 \% \\
\text { TX-100 } \\
\end{array}$ & - & $\begin{array}{c}1.38 \text { or } \\
1.48\end{array}$ & $\begin{array}{l}\text { Very } \\
\text { strong }\end{array}$ & $\begin{array}{c}\text { Neonatal } \\
\text { marmoset } \\
\text { brain }\end{array}$ & $1-2$ weeks & \multirow{2}{*}{++} & - & \multirow{2}{*}{ Expansion } & $\begin{array}{l}\text { Yes } \\
\text { (small) }\end{array}$ & - & 3 & $\begin{array}{l}\text { Susaki et } \\
\text { al., 2014 }\end{array}$ \\
\hline $\begin{array}{l}\text { CUBIC- } \\
\text { Perfusion }\end{array}$ & $\begin{array}{c}\text { 4M urea, } \\
\text { aminoalco- } \\
\text { hols }\end{array}$ & $\begin{array}{c}15 \% \text { or } \\
0.1 \% \\
\text { TX- } 100 \\
\end{array}$ & - & 1.38 & $\begin{array}{l}\text { Very } \\
\text { strong }\end{array}$ & Adult mouse & $\begin{array}{l}2 \text { weeks } \\
\text { (whole } \\
\text { body) } \\
\end{array}$ & & - & & $\begin{array}{c}\text { Yes } \\
\text { (small) }\end{array}$ & - & 2 & $\begin{array}{l}\text { Tainaka et } \\
\text { al., } 2014\end{array}$ \\
\hline \multicolumn{15}{|c|}{ Tissue-gel hybridization followed by delipidation and RI matching } \\
\hline \multicolumn{15}{|c|}{ Electrophoresis-assisted delipidation } \\
\hline CLARITY & $\begin{array}{l}\text { SDS, } \\
\text { FocusClear }\end{array}$ & $4 \%$ SDS & $\begin{array}{l}\text { A4P4 } \\
\text { B0.05 or } \\
\text { A0.5P4 } \\
\text { B0.0125 }\end{array}$ & 1.45 & $\begin{array}{l}\text { Very } \\
\text { strong }\end{array}$ & $\begin{array}{l}\text { Adult mouse } \\
\text { brain; } 500-\mu \mathrm{m}- \\
\text { thick post- } \\
\text { mortem human } \\
\text { brain }\end{array}$ & 2-4 weeks & ++ & - & \multirow{3}{*}{$\begin{array}{c}\text { Minimal } \\
\text { expansion }\end{array}$} & $\begin{array}{c}\text { Yes } \\
\text { (large); } \\
\text { multi-round } \\
(\leq 3)\end{array}$ & ISH (small') & 11 & $\begin{array}{l}\text { Chung et } \\
\text { al., 2013; } \\
\text { Tomer et } \\
\text { al., } 2014\end{array}$ \\
\hline $\begin{array}{l}\text { SE- } \\
\text { CLARITY } \\
\end{array}$ & $\begin{array}{l}\text { SDS, custom } \\
\text { RI matching } \\
\text { solution } \\
\end{array}$ & $\begin{array}{l}200 \mathrm{mM} \\
\mathrm{SDS}\end{array}$ & A4P4 & 1.46 & $\begin{array}{l}\text { Very } \\
\text { strong }\end{array}$ & $\begin{array}{l}\text { Adult mouse } \\
\text { brain }\end{array}$ & $1-3$ days & ++ & - & & $\begin{array}{l}\text { Yes } \\
\text { (large) }\end{array}$ & Not tested & 3 & $\begin{array}{l}\text { Kim et al., } \\
2015\end{array}$ \\
\hline $\begin{array}{l}\text { ACT- } \\
\text { PRESTO }\end{array}$ & $\begin{array}{l}\text { SDS, RIMS* } \\
\text { (or CUBIC- } \\
\text { mount) }\end{array}$ & $4 \%$ SDS & A4P0 & $\begin{array}{l}1.43- \\
1.48\end{array}$ & $\begin{array}{l}\text { Very } \\
\text { strong }\end{array}$ & $\begin{array}{l}\text { Adult rabbit } \\
\text { brain (modest } \\
\text { transparency) }\end{array}$ & 2-3 days & ++ & - & & $\begin{array}{l}\text { Yes } \\
\text { (large) }\end{array}$ & ISH & 75 & $\begin{array}{l}\text { Lee et al., } \\
2016\end{array}$ \\
\hline \multicolumn{15}{|c|}{ Passive delipidation } \\
\hline РАCT & SDS, RIMS & $8 \%$ SDS & A4P0 & $\begin{array}{l}1.38- \\
1.48 \\
\end{array}$ & $\begin{array}{c}\text { Very } \\
\text { strong }\end{array}$ & \multirow{2}{*}{$\begin{array}{l}\text { Adult mouse } \\
\text { brain and } \\
\text { whole-body }\end{array}$} & $\geq 1$ month & ++ & - & \multirow{2}{*}{$\begin{array}{c}\text { Minimal } \\
\text { expansion }\end{array}$} & $\begin{array}{c}\text { Yes } \\
\text { (large) }\end{array}$ & $\begin{array}{l}\text { smFISH } \\
(\text { (small') }\end{array}$ & 8 & $\begin{array}{l}\text { Yang, et } \\
\text { al., 2014 } \\
\end{array}$ \\
\hline PARS & SDS, RIMS & $8 \%$ SDS & A4P0 & $\begin{array}{l}1.38- \\
1.48 \\
\end{array}$ & $\begin{array}{l}\text { Very } \\
\text { strong }\end{array}$ & & $1-2$ weeks & ++ & - & & $\begin{array}{c}\text { Yes } \\
\text { (large) }\end{array}$ & Not tested & 6 & $\begin{array}{l}\text { Yang, et } \\
\text { al., 2014 } \\
\end{array}$ \\
\hline $\begin{array}{l}\text { EDC- } \\
\text { CLARITY }\end{array}$ & $\begin{array}{l}\text { SDS, Focus- } \\
\text { Clear }\end{array}$ & $4 \%$ SDS & $\begin{array}{l}\text { A4P4B0.0 } \\
5 \text { or } \\
\text { A4P0; } 0.1 \\
\text { M EDC }\end{array}$ & 1.45 & $\begin{array}{l}\text { Very } \\
\text { strong }\end{array}$ & $\begin{array}{l}\text { Adult mouse } \\
\text { brain }\end{array}$ & 2-4 weeks & ++ & - & $\begin{array}{c}\begin{array}{c}\text { Shrinkage } \\
\text { (during }\end{array} \\
\text { hybridization } \\
\text { and } \\
\text { stringency } \\
\text { wash) }\end{array}$ & Not tested & $\begin{array}{l}\text { Multiplexed } \\
\text { ISH using } \\
\text { DNA- } \\
\text { based } \\
\text { amplifica- } \\
\text { tion (large') }\end{array}$ & 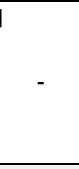 & $\begin{array}{l}\text { Sylwestrak } \\
\text { et al., } 2016\end{array}$ \\
\hline \multicolumn{15}{|c|}{ GA fixation followed by thermal delipidation } \\
\hline SWITCH & $\begin{array}{l}\text { SDS, custom } \\
\text { RI matching } \\
\text { solution }\end{array}$ & $\begin{array}{l}200 \mathrm{mM} \\
\mathrm{SDS}\end{array}$ & $\begin{array}{c}\text { G1P4; } \\
\text { pH 34\% } \\
\text { GA, pH } 7 \\
1 \% \text { GA }\end{array}$ & 1.47 & $\begin{array}{l}\text { Very } \\
\text { strong } \\
\text { (mild } \\
\text { browning) }\end{array}$ & $\begin{array}{l}\text { Adult rat and } \\
\text { young marmo- } \\
\text { set brains }\end{array}$ & $\begin{array}{c}4 \text { days-2 } \\
\text { weeks }\end{array}$ & - & + & $\begin{array}{l}\text { Minimal } \\
\text { expansion; } \\
\text { hardened }\end{array}$ & $\begin{array}{c}\text { Yes } \\
\text { (large); } \\
\text { multi-round } \\
(>20)\end{array}$ & - & 86 & $\begin{array}{l}\text { Murray et } \\
\text { al., 2015 }\end{array}$ \\
\hline
\end{tabular}

${ }^{\mathrm{a}}$ The largest brain tissue used in the original studies.

${ }^{b}$ Time required for clearing a whole mouse brain or hemisphere (not including staining).

${ }^{c}++$, FP signal retained for more than a week; +, FP signal retained for less than a week; -, FP signal not preserved.

${ }^{d}$ Qualitative evaluations based on recent comparative experiments (Economo et al., 2016; Hama et al., 2015).

'Large' indicates millimeter-scale samples such as whole organs. Note that immunostaining compatibility was not demonstrated in the original ScaleS paper (alternative protocol termed AbScale is required for immunostaining).

CLARITY demonstrated in situ hybridization in 500- $\mu \mathrm{m}$ brain blocks. smFISH was demonstrated in PACT-processed $100-\mu \mathrm{m}$ brain slices. In EDCCLARITY method, specific RNAs were detected in 2-mm block of mouse cortex by DNA-based signal amplification method (Hybridization Chain Reaction). 
hydroxyl groups in the medium (Mao et al., 2008). Likewise, a high-RI zinc iodide solution was ineffective in clearing brain tissues (Ke et al., 2013), and 85\% glycerol solution did not clear the tissue as efficiently as FocusClear, although the two solutions have approximately same RI (Chung et al., 2013). These indicate that chemical properties of the medium, as well as physical properties such as RI, strongly influence tissue transparency; comprehensive investigations on the mechanism of tissue clearing will be necessary to rationalize and refine existing tissue clearing protocols in the coming years.

\section{DELIPIDATION AND DEHYDRATION/HYPERHYDRATION FOLLOWED BY REFRACTIVE INDEX MATCHING}

Lipids are a major source of light scattering in biological samples because of their high RI and their tendency to form granular structures (main reason for tissue's milky appearance) (Tuchin, 2015). As such, many clearing techniques remove lipids from the sample to achieve optical homogeneity and transparency. The methods that involve delipidation step can be sub-divided into two groups, one that uses organic solvents and the other that utilizes urea and detergents. Each typically involves dehydration and hyperhydration, respectively.

Clearing methods based on organic solvents, such as 3DISCO, dehydrate a tissue to render the tissue optically homogeneous ( $\mathrm{Rl}$ of dehydrated proteins is $>1.5$ ) and match the $\mathrm{RI}$ with the solvents (RI 1.56). The solvent-based methods have better optical clearing capability and are generally faster than the simple immersions; they yield more transparent samples than Clear $^{\top}$, Clear $^{\top 2}$ and SeeDB (Hama et al., 2015), and benzyl alcohol and benzyl benzoate (BABB)-based method and 3DISCO can clear a whole mouse brain in 2-3 days (Dodt et al., 2007; Ertürk et al., 2012a). The organic solvents rapidly quench FPs, however, severely restricting time for imaging and storage. For example, 3DISCO uses dibenzyl ether (DBE) and tetrahydrofuran (THF) to better retain the fluorescence emissions, but the half-life of green fluorescent protein (GFP) signal in the final clearing solution was still only 1-2 days (Ertürk et al., 2012b). As an alternative, in iDISCO, molecules of interests are immunolabeled with antibodies conjugated with Alexa Fluor that are relatively stable in organic solvents, to circumvent the FP quenching problem (Renier et al., 2014). Additionally, the dehydrated and delipidated tissues are substantially shrunken in organic solvents, which may be advantageous for imaging a large volume due to the reduced size, albeit at a reduced resolution (Hama et al., 2015; Richardson and Lichtman, 2015). In these methods, the toxic organic solvents must be carefully handled.

Aqueous-based solutions containing non-ionic detergents (e.g. Triton X-100) and denaturants (e.g. urea) can also clear tissues effectively with less of the quenching and toxicity problems. In these methods, the detergents remove lipids, while the urea solution partially denatures endogenous proteins, facilitates hyperhydration of biomolecules (Hua et al., 2008; Richardson and Lichtman, 2015), and matches the overall tissue RI to 1.38 (Hama et al., 2011). ScaleA2, ScaleS, CUBIC and CUBIC-perfusion are the examples of such methods. CUBIC protocol uses basic aminoalcohol-based cocktails in addition to urea and Triton X-100 to enhance its clearing capability (Susaki et al., 2014). A modified CUBIC clearing reagent-used in CUBIC-perfusion-elutes hemechromophores from red blood cells, the principal light absorber in the blood, to further increase tissue transparency (Tainaka et al., 2014). Perfusing the CUBIC solution for two weeks can clear a whole body of infant and adult mouse while preserving FPs (Susaki et al., 2015; Tainaka et al., 2014). These methods are beneficial due to the use of nontoxic reagents, ease of implementation, and their strong clearing capability, but the samples can be damaged by hydration-induced expansion (urea can expand samples considerably as shown in ScaleA2-1.28x linearlywhich can distort micro- and macrostructures of the tissues; Hama et al., 2011) and high concentration of detergents. ScaleS uses sorbitol, a mild tissue-permeant sugar alcohol with dehydrating property, to counterbalance the tissue expansion caused by urea (Hama et al., 2015). In addition, ScaleS incorporates $\leq 0.2 \%$ of Triton $X-100$ to avoid compromising tissue integrity and attenuating fluorescence signals (Hama et al., 2015). As such, ScaleS preserves the ultrastructure (evaluated by electron microscopy) that is damaged in other techniques (Hama et al., 2015).

\section{TISSUE-GEL HYBRIDIZATION FOLLOWED BY DELIPIDATION AND REFRACTIVE INDEX MATCHING}

Native biomolecules and their contextual information can be lost during harsh clearing conditions that involve organic solvents or high concentrations of detergents. In CLARITY and its variants, a gel is embedded throughout a tissue to effectively transmute the sample into a tissue-gel hybrid, wherein the gel network provides an extra support for the biological structures and bolsters tissue integrity (Chung et al., 2013; Kim et al., 2015; Murray et al., 2015; Tomer et al., 2014; Yang et al., 2014) The tissue-gel hybrid can undergo extensive delipidation by strong ionic detergent, sodium dodecyl sulfate (SDS), while well-preserving structures and molecules covalently linked to the gel network. Delipidation can be achieved by slow but simple incubation in the SDS solution for several weeks (Tomer et al., 2014), but can also be expedited by electrophoresis (Chung et al., 2013; Tomer et al., 2014), a newly devised electrophoresis strategy termed stochastic electrotransport (Kim et al., 2015), thermal energy (Murray et al., 2015), or perfusion of SDS solution (Yang et al., 2014). Delipidated samples are immersed in commercially available RI-matching solutions (e.g. FocusClear or Easy-Index) or custom-made solutions (e.g. RIMS, 2,2'-thiodiethanol (TDE), 80\% glycerol, CUBIC-mount or other unnamed recipes) for full optical clearing (Aoyagi et al., 2015; Chung et al., 2013; Costantini et al., 2015; Kim et al., 2015; Lee et al., 2016; Yang et al., 2014). CLARITY, PACT, PARS, stochastic electrotransport and SWITCH all exhibit very strong clearing performance, owing to the effective lipid removal (Chung et al., 2013; Hama et al., 2015; Kim et al., 2015; Murray et al., 2015; Tomer et al., 2014; Yang et al., 2014). These methods do not quench FPs (with the exception of SWITCH, which uses heat to expedite clearing) and use mostly nontoxic chemicals. The clearing time varies depending on how lipids are removed, with the passive incubation being the slowest (more than a month for a mouse brain) and the stochastic electrotransport the fastest (2-3 days for a mouse brain). Notably, delipidation increases hybrid porosity, facilitating the diffusion of molecular probes (e.g. antibodies) for labeling.

The original CLARITY employs electrophoresis for lipid removal, but this requires a special electrophoresis chamber and the protocol is difficult to implement. Also, the strong electric field can compromise the molecular and structural integrity of the tissue, as the electric field exerts forces on the charged endogenous biomolecules (e.g. nucleic acids and proteins) as well as the SDS micelles. Three CLARITY-based approaches have been developed with the motivation to address these problems: (1) low-density tissue-gel hybrid formation followed 
by passive delipidation (passive CLARITY, PACT and PARS), (2) high-density dialdehyde-tissue-gel formation followed by thermally facilitated delipidation (SWITCH) and (3) stochastic electrotransport-assisted active delipidation.

Passive CLARITY, PACT and PARS use low concentrations (even zero) of fixatives and hydrogel monomers (acrylamide and bis-acrylamide) to allow users to clear large samples simply and easily by incubating in SDS solution within a reasonable timeframe (weeks) (Tomer et al., 2014; Yang et al., 2014). Reducing tissue-hydrogel hybrid density effectively facilitates the diffusion of bulky SDS micelles, but at the cost of structural and molecular integrity, requiring special attention for optimizing the hydrogel composition and clearing condition.

In contrast, SWITCH takes the opposite approach of transforming a tissue to an even denser and more robust hybrid structure that allows using harsh conditions to expedite clearing. In SWITCH, glutaraldehyde (GA), a bifunctional crosslinker, is infused throughout the tissue, crosslinking biomolecules much more strongly than formaldehyde used in other methods. This significantly increases the heat-, chemical- and physical resistance of the sample (Hopwood, 1972; Murray et al., 2015; Sung et al., 1996), allowing for efficient passive clearing at high temperatures of $70-80^{\circ} \mathrm{C}$ without compromising the molecular and structural integrity of the sample. This approach is simple and rapid (adult mouse hemisphere cleared in $12 \mathrm{~h}$ at $80^{\circ} \mathrm{C}$ ) (Murray et al., 2015). However, fluorescence is lost under the harsh condition, which necessitates the additional labeling.

Stochastic electrotransport is a new electrokinetic method using a rotational electric field to selectively facilitate the dispersion of highly electromobile molecules, such as SDS micelles (Kim et al., 2015). This technique also uses a temperaturecontrolled circulating system to prevent Joule heating from damaging the sample and nanoporous membranes to minimize the electrolysis of SDS (Kim et al., 2015). When applied to gelembedded tissues to remove lipids, stochastic electrotransport can substantially accelerate the clearing process $(\sim 10$ times faster than the original CLARITY method) without damaging the tissue sample or quenching the FPs (Kim et al., 2015). Stochastic electrotransport requires even more complex electrophoresis device for its implementation than CLARITY does, but the device and the associated buffers are commercially available.

\section{LABELING TECHNIQUES FOR LARGE-SCALE TISSUES}

How can we observe and extract useful structural and contextual biological information from the cleared tissues? Labeling structures or molecules of interest with (usually fluorescent) molecular probes is critical for visualizing the targets inside the transparent tissue in most experiments (unless the cleared sample is pre- or transgenically labeled and the fluorescence is well preserved throughout the clearing process). Particularly useful are the methods enabling highly multiplexed and/or multi-round labeling, for the extraction of maximal amount of information from each sample. Conventional labeling techniques such as immunohistochemistry rely on slow diffusion of molecular probes, which takes impractically long time for the samples beyond the millimeter scale. Also, the conventional techniques are limited in multiplexing capabilities and usually support less than 2-3 rounds of repeated labeling. Thus, a pressing need has arisen for a means of expediting the transportation of macromolecular probes into the large volume of tissues, while supporting highly multiplexed, multi-round labeling of the tissues. Recent development of such techniques employs the following approaches: (1) increasing sample permeability, (2) applying external forces, and (3) increasing probe concentration gradient and modulating probe-target binding reaction kinetics.

Other approaches include irradiating samples with microwave to facilitate molecular transport (Gleave et al., 2013) and perfusing molecular probes to utilize the circulatory systems of the body to reduce the reach for the targets (Yang et al., 2014), but these attempts are yet to demonstrate successful labeling of a large volume of tissues.

\section{INCREASING SAMPLE PERMEABILITY FOR WHOLE- MOUNT LABELING}

To speed up molecular penetration, conventionally, tissues have been permeabilized by reducing fixation, applying detergents, repeating freeze-thaw cycle, repeating dehydrationrehydration cycle or mix-and-matching of these methods (Gleave et al., 2013; Long and Buggs, 2008; Sillitoe and Hawkes, 2002). Recently, iDISCO dehydrated, bleached and rehydrated the tissue to achieve successful whole-mount immunolabeling of large organs (rodent brain, kidney, lung, or spinal cord) in 8-18 days (Renier et al., 2014). While the large-scale probe penetration and retainment are remarkable, iDISCO has limited multiplexing and multi-round staining capability. Renier and colleagues demonstrated simultaneous imaging of only up to two channels due to heightened autofluorescence, and the samples were subjected to irreversible clearing procedure with organic solvents, which prevented multi-round labeling.

CLARITY demonstrated immunolabeling of a whole adult mouse brain in six weeks, and three rounds of labeling with up to 4 channels (Chung et al., 2013). The sample cannot be labeled more than three rounds, since the hydrogel loses integrity during harsh elution condition (Murray et al., 2015). Passive CLARITY and PACT further reduce the density of the hydrogel network, facilitating the diffusion of labeling probes deeper into the tissue. The reduced crosslink density in the methods, however, may adversely affect the integrity of endogenous molecules to be labeled (e.g. reduced antigenicity or increased protein leaching), limiting multi-round labeling (Tomer et al., 2014; Yang et al., 2014).

\section{APPLYING EXTERNAL FORCES FOR WHOLE-MOUNT LABELING}

External forces can accelerate the transport of slowly diffusing labeling probes. For example, hydrodynamic pressure can generate convective flow in porous samples to accelerate molecular transportations. c-PRESTO and s-PRESTO employ centrifugation and syringe pump, respectively, to apply pressure and improve the diffusion of antibodies into tissue samples (Lee et al., 2016). The 30- to $100-\mu \mathrm{m}$-thick sections could be labeled with these methods within 2-3 h, but these have not been applied to a large volume of tissues. Sufficiently high pressures required to generate strong flow inside a large sample may adversely damage the tissues.

An electric field exerts force on electrically charged molecules and thus can be more selective than hydrodynamic pressure. A strong electric field, however, can damage the sample since some tissue components as well as the molecular probes are charged. Stochastic electrotransport effectively amplifies the electromobility differences between the tissue and the molecular probes, thereby selectively enhancing the transport of the probes (Kim et al., 2015). Using stochastic electrotransport, cleared mouse organs can be rapidly and completely stained with nuclear dyes (SYTO 16), proteins (lectin), and antibodies 
within one day. Stochastic electrotransport-assisted whole-mount labeling is compatible with the tissues cleared with CLARITY, CUBIC and SWITCH (Kim et al., 2015; unpublished observations).

\section{INCREASING CONCENTRATION GRADIENT AND MODULATING PROBE-TARGET BINDING REACTION KINETICS}

SWITCH enhances probe penetration by increasing the concentration gradient of the probes (i.e. using high concentration of probes) and controlling kinetics of probe-target binding reactions inside a tissue (Murray et al., 2015). Using high concentration of probes can lead to high level of nonspecific binding and saturated signals at the surface; to tackle this issue, SWITCH uses a set of buffers (SWITCH-Off \& SWITCH-On) that reversibly modulate chemical reaction kinetics. Specifically, SWITCH-Off buffer inhibits the binding reaction between the labeling probes and their targets, and SWITCH-On buffer facilites the reaction. In SWITCH-Off buffer, molecular probes (e.g. antibodies) are first dispersed throughout the tissue. The buffer is then "switched" to SWITCH-On buffer, enabling the binding reaction to occur. In this way, SWITCH enhances both probe penetration and labeling uniformity - myelinated fibers throughout a mouse hemisphere could be uniformly stained in 9 days. Furthermore, SWITCH transforms a tissue into a robust dialdehyde-tissue-gel, which can support more rounds of labeling and elution. With this method, 22 rounds of antibody labeling were demonstrated in a single tissue (Murray et al., 2015).

\section{DISCUSSION AND CONCLUSION}

Understanding complex biological systems in native 3D context has long been an unmet goal in biology and medicine, mainly due to the physical constraints imposed by light scattering and slow molecular diffusion. Recent advances in clearing and labeling techniques significantly improved scalability and throughput, making tissue-level investigations more accessible than ever before; the techniques have been applied to a wide range of biological systems, from a small mouse embryo to mouse whole organs, marmoset brains, postmortem human brain tissues and even plant organs (ClearSee and PEA-CLARITY demonstrated clearing of plant tissues; see Kurihara et al., 2015; Palmer et al., 2015; Warner et al., 2014). While more creative methods will be developed and introduced to the field, immediate improvements can be made by combining strengths of the existing methods. For example, the concept of SWITCH can be combined with other immersion-based clearing methods to facilitate uniform molecular delivery into the tissue, or with stochastic electrotransport to further accelerate clearing and labeling.

A common challenge in all tissue clearing and labeling techniques is the lack of quantitative measurement on the loss of molecular integrity during tissue processing. In most reports, a few microscopic images from a small portion of the sample are used to demonstrate the retention of nucleic acids and proteins. However, this cannot convincingly demonstrate the molecular integrity of the tissue; at the very least, quantitative biochemical measurements on the loss of biomolecules should be accompanied as complementary measures. Most simple immersion, hyperhydration, and solvent-based clearing methods published thus far did not quantitatively measure the loss of biomolecules, even though significant loss of proteins as well as lipids is likely to occur during the incubation in organic solvents, urea, and detergents. Only EDC-CLARITY (a recently published variation to CLARITY that uses carbodiimide-based chemistry to im- prove RNA preservation and detection in the tissue-gel hybrid network) provides comprehensive and quantitative measurements of RNA retention (Sylwestrak et al., 2016). Likewise, we believe that future tissue clearing protocols should set and follow rigorous experimental standards for measuring the loss of molecular information, as developing more preservative tissue processing techniques will become more important in the coming years (Pallotto et al., 2015).

Decreased or quenched FP signal and increased autofluorescence after tissue processing present another challenge. Essentially all tissue clearing and labeling techniques expose the sample to the condition that partially or fully quenches FP signal, and alter biochemical properties of the tissue that sometimes result in increased autofluorescence (e.g. arising from Schiff bases formed by aldehyde fixation). While minimizing such alterations is a way to approach the problem, amplifying the fluorescence signals of target molecules could also effectively address the issue. For example, recent advances in molecular amplification tools, such as SunTag (protein, up to 24fold) and hybridization chain reaction (mRNA, approximately 200-fold), can be synergistically combined with tissue clearing to enable deep and stable imaging (Choi et al., 2010; 2014; Tanenbaum et al., 2014). Most recently, EDC-CLARITY leveraged hybridization chain reaction to detect microRNAs and mRNAs in clarified mouse and human tissues (Sylwestrak et al. 2016). Such signal amplification would enable imaging of lowcopy-number molecules with long working distance objective lenses, which have limited numerical aperture.

High-throughput imaging of a large volume of cleared tissues is a significant challenge, as conventional scanning-based microscopy (e.g. confocal or two-photon laser scanning microscopy) would take many weeks to months for sub-cellular resolution imaging of a cubic centimeter-sized tissue. This issue is now addressable with emerging light-sheet microscopy (LSM) (Keller and Ahrens, 2015). LSM is advantageous in that its configuration not only allows for fast imaging by simultaneous illumination of an entire plane, but also reduces the energy load of excitation light on the specimen, thereby minimizing photobleaching and phototoxic effects. Among the various LSM techniques, COLM (CLARITY-Optimized Light-sheet Microscopy), the LSM method optimized for CLARITY-processed large-scale tissues, can achieve imaging of an entire mouse brain in several hours-two orders of magnitude faster than conventional scanning-based microscopy (Tomer et al., 2014). Recently developed SPED (SPherical-aberration-assisted Extended Depth-of-field) light sheet microscopy further increases the imaging speed by extending the detection depth of field, which eliminates the requirement to move heavy detection objectives (Tomer et al., 2015).

The resulting terabytes of massive volumetric images is already calling for the extensive innovation in data management and analysis. At the same time, we must find ways to turn the vast amount of data from organ-wide experiments into new biological insights and discoveries. Clearing and labeling methods for large-scale biological tissues will continue to evolve in the coming years, and so will imaging and analysis technologies. With concerted and collaborative efforts, molecular, chemical, and optical profiling of large-scale biological systems will find many more applications in the near future.

\section{ACKNOWLEDGMENTS}

We thank the entire Kim lab for helpful discussions. S.-Y.K. is supported by Research Resettlement Fund for the new faculty of Seoul National University, the TJ Park Science Fellowship of POSCO TJ Park Foundation and a grant of the Korea Health 
Technology R\&D Project through the Korea Health Industry Development Institute (KHIDI), funded by the Ministry of Health \& Welfare, Republic of Korea (grant number: HI15C1234).

\section{REFERENCES}

Aoyagi, Y., Kawakami, R., Osanai, H., Hibi, T., and Nemoto, T. (2015). A rapid optical clearing protocol using 2,2'-thiodiethanol for microscopic observation of fixed mouse brain. Plos One 10, e0116280.

Bolin, F.P., Preuss, L.E., Taylor, R.C., and Ference, R.J. (1989). Refractive index of some mammalian tissues using a fiber optic cladding method. Appl. Opt. 28, 2297.

Choi, B., Tsu, L., Chen, E., Ishak, T.S., Iskandar, S.M., Chess, S., and Nelson, J.S. (2005). Determination of chemical agent optical clearing potential using in vitro human skin. Lasers Surg. Med. 36, 72-75.

Choi, H.M.T., Chang, J.Y., Trinh, L.A., Padilla, J.E., Fraser, S.E., and Pierce, N.A. (2010). Programmable in situ amplification for multiplexed imaging of mRNA expression. Nat. Biotechnol. 28, 1208-1212.

Choi, H.M.T., Beck, V.A., and Pierce, N.A. (2014). Next-generation in situ hybridization chain reaction: higher gain, lower cost, greater durability. ACS Nano 8, 4284-4294.

Chung, K., Wallace, J., Kim, S.-Y., Kalyanasundaram, S., Andalman, A.S., Davidson, T.J., Mirzabekov, J.J., Zalocusky, K.A., Mattis, J., Denisin, A.K., et al. (2013). Structural and molecular interrogation of intact biological systems. Nature 497, 332-337.

Costantini, I., Ghobril, J.-P., Di Giovanna, A.P., Mascaro, A.L.A., Silvestri, L., Müllenbroich, M.C., Onofri, L., Conti, V., Vanzi, F., Sacconi, L., et al. (2015). A versatile clearing agent for multimodal brain imaging. Sci. Rep. 5, 9808.

Dodt, H.-U., Leischner, U., Schierloh, A., Jährling, N., Mauch, C.P., Deininger, K., Deussing, J.M., Eder, M., Zieglgänsberger, W., and Becker, K. (2007). Ultramicroscopy: three-dimensional visualization of neuronal networks in the whole mouse brain. Nat. Methods 4, 331-336.

Economo, M.N., Clack, N.G., Lavis, L.D., Gerfen, C.R., Svoboda, K., Myers, E.W., and Chandrashekar, J. (2016). A platform for brain-wide imaging and reconstruction of individual neurons. eLife 5, e10566.

Ertürk, A., Becker, K., Jährling, N., Mauch, C.P., Hojer, C.D., Egen, J.G., Hellal, F., Bradke, F., Sheng, M., and Dodt, H.-U. (2012a). Three-dimensional imaging of solvent-cleared organs using 3DISCO. Nat. Protoc. 7, 1983-1995.

Ertürk, A., Mauch, C.P., Hellal, F., Förstner, F., Keck, T., Becker, K., Jährling, N., Steffens, H., Richter, M., Hübener, M., et al. (2012b). Three-dimensional imaging of the unsectioned adult spinal cord to assess axon regeneration and glial responses after injury. Nat. Med. 18, 166-171.

Gleave, J.A., Lerch, J.P., Henkelman, R.M., and Nieman, B.J. (2013). A method for 3D immunostaining and optical imaging of the mouse brain demonstrated in neural progenitor cells. PloS One 8, e72039-e72039.

Hama, H., Kurokawa, H., Kawano, H., Ando, R., Shimogori, T., Noda, H., Fukami, K., Sakaue-Sawano, A., and Miyawaki, A. (2011). Scale: a chemical approach for fluorescence imaging and reconstruction of transparent mouse brain. Nat. Neurosci. 14, 1481-1488.

Hama, H., Hioki, H., Namiki, K., Hoshida, T., Kurokawa, H., Ishidate, F., Kaneko, T., Akagi, T., Saito, T., Saido, T., et al. (2015). ScaleS: an optical clearing palette for biological imaging. Nat. Neurosci. 18, 1518-1529.

Hofman, F.M., and Taylor, C.R. (2001). Immunohistochemistry. In current protocols in immunology. (John Wiley \& Sons, Inc.).

Hopwood, D. (1972). Theoretical and practical aspects of glutaraldehyde fixation. Histochem. J. 4, 267-303.

Hua, L., Zhou, R., Thirumalai, D., and Berne, B.J. (2008). Urea denaturation by stronger dispersion interactions with proteins than water implies a 2-stage unfolding. Proc. Natl. Acad. Sci. 105, 16928-16933.

Huang, D., Swanson, E.A., Lin, C.P., Schuman, J.S., Stinson, W.G., Chang, W., Hee, M.R., Flotte, T., Gregory, K., Puliafito, C.A., et al. (1991). Optical coherence tomography. Science 254, 1178-1181.

Ke, M.-T., Fujimoto, S., and Imai, T. (2013). SeeDB: a simple and morphology-preserving optical clearing agent for neuronal circuit reconstruction. Nat. Neurosci. 16, 1154-1161.

Keller, P.J., and Ahrens, M.B. (2015). Visualizing whole-brain activity and development at the single-cell level using light-sheet microscopy. Neuron 85, 462-483.

Kim, S.-Y., Chung, K., and Deisseroth, K. (2013). Light microscopy mapping of connections in the intact brain. Trends Cogn. Sci. 17, 596-599.

Kim, S.-Y., Cho, J.H., Murray, E., Bakh, N., Choi, H., Ohn, K., Ruelas, L., Hubbert, A., McCue, M., Vassallo, S.L., et al. (2015). Stochastic electrotransport selectively enhances the transport of highly electromobile molecules. Proc. Natl. Acad. Sci. U SA 112, E6274-E6283.

Kurihara, D., Mizuta, Y., Sato, Y., and Higashiyama, T. (2015). ClearSee: a rapid optical clearing reagent for whole-plant fluorescence imaging. Dev. Camb. Engl. 142, 4168-4179.

Kuwajima, T., Sitko, A.A., Bhansali, P., Jurgens, C., Guido, W., and Mason, C. (2013). ClearT: a detergent- and solvent-free clearing method for neuronal and non-neuronal tissue. Development 140, 1364-1368.

Lee, E., Choi, J., Jo, Y., Kim, J.Y., Jang, Y.J., Lee, H.M., Kim, S.Y., Lee, H.-J., Cho, K., Jung, N., et al. (2016). ACT-PRESTO: Rapid and consistent tissue clearing and labeling method for 3dimensional (3D) imaging. Sci. Rep. 6,18631.

Long, D.J., and Buggs, C. (2008). Microwave oven-based technique for immunofluorescent staining of paraffin-embedded tissues. J. Mol. Histol. 39, 1-4.

Mao, Z., Zhu, D., Hu, Y., Wen, X., and Han, Z. (2008). Influence of alcohols on the optical clearing effect of skin in vitro. J. Biomed. Opt. 13, 021104.

McGurk, L., Morrison, H., Keegan, L.P., Sharpe, J., and O'Connell, M.A. (2007). Three-Dimensional Imaging of Drosophila melanogaster. PLoS One 2, e834.

Muehllehner, G., and Karp, J.S. (2006). Positron emission tomography. Phys. Med. Biol. 51, R117.

Murray, E., Cho, J.H., Goodwin, D., Ku, T., Swaney, J., Kim, S.-Y., Choi, H., Park, Y.-G., Park, J.-Y., Hubbert, A., et al. (2015). Simple, scalable proteomic imaging for high-dimensional profiling of intact systems. Cell 163, 1500-1514.

Pallotto, M., Watkins, P.V., Fubara, B., Singer, J.H., and Briggman, K.L. (2015). Extracellular space preservation aids the connectomic analysis of neural circuits. eLife 4.

Palmer, W.M., Martin, A.P., Flynn, J.R., Reed, S.L., White, R.G., Furbank, R.T., and Grof, C.P.L. (2015). PEA-CLARITY: 3D molecular imaging of whole plant organs. Sci. Rep. 5, 13492.

Reiser, M.F., Semmler, W., and Hricak, H. (2007). Magnetic Resonance Tomography (Springer Science \& Business Media).

Renier, N., Wu, Z., Simon, D.J., Yang, J., Ariel, P., and TessierLavigne, M. (2014). iDISCO: a simple, rapid method to immunolabel large tissue samples for volume Imaging. Cell 159, 896-910.

Richardson, D.S., and Lichtman, J.W. (2015). Clarifying tissue clearing. Cell 162, 246-257.

Sillitoe, R.V., and Hawkes, R. (2002). Whole-mount immunohistochemistry: a high-throughput screen for patterning defects in the mouse cerebellum. J. Histochem. Cytochem. 50, 235-244.

Spalteholz, W. (1914). Über das Durchsichtigmachen von menschlichen und tierischen Präparaten (Leipzig: S. Hierzel).

Sung, H.-W., Hsu, H.-L., Shih, C.-C., and Lin, D.-S. (1996). Crosslinking characteristics of biological tissues fixed with monofunctional or multifunctional epoxy compounds. Biomaterials 17, 1405-1410.

Susaki, E.A., and Ueda, H.R. (2016). Whole-body and whole-organ clearing and imaging techniques with single-cell resolution: toward organism-level systems biology in mammals. Cell Chem. Biol. 23, 137-157.

Susaki, E.A., Tainaka, K., Perrin, D., Kishino, F., Tawara, T., Watanabe, T.M., Yokoyama, C., Onoe, H., Eguchi, M., Yamaguchi, S., et al. (2014). Whole-brain imaging with single-cell resolution using chemical cocktails and computational Analysis. Cell 157, 726-739.

Susaki, E.A., Tainaka, K., Perrin, D., Yukinaga, H., Kuno, A., and Ueda, H.R. (2015). Advanced CUBIC protocols for whole-brain and whole-body clearing and imaging. Nat. Protoc. 10, 1709-1727.

Sylwestrak, E.L., Rajasethupathy, P., Wright, M.A., Jaffe, A., and Deisseroth, K. (2016). Multiplexed intact-tissue transcriptional analysis at cellular resolution. Cell 164, 792-804.

Tainaka, K., Kubota, S.I., Suyama, T.Q., Susaki, E.A., Perrin, D., 
Ukai-Tadenuma, M., Ukai, H., and Ueda, H.R. (2014). Wholebody imaging with single-cell resolution by tissue decolorization. Cell 159, 911-924.

Tanenbaum, M.E., Gilbert, L.A., Qi, L.S., Weissman, J.S., and Vale, R.D. (2014). A protein-tagging system for signal amplification in gene expression and fluorescence imaging. Cell 159, 635-646.

Tomer, R., Ye, L., Hsueh, B., and Deisseroth, K. (2014). Advanced CLARITY for rapid and high-resolution imaging of intact tissues. Nat. Protoc. 9, 1682-1697.

Tomer, R., Lovett-Barron, M., Kauvar, I., Andalman, A., Burns, V.M., Sankaran, S., Grosenick, L., Broxton, M., Yang, S., and Deisseroth, K. (2015). SPED light sheet microscopy: fast mapping of biological system structure and function. Cell 163, 1796-1806.
Tuchin, V.V. (2015). Tissue optics and photonics: light-tissue interaction. J. Biomed. Photonics Eng. 1, 98-134.

Van Essen, D.C., Smith, S.M., Barch, D.M., Behrens, T.E.J., Yacoub, E., and Ugurbil, K. (2013). The WU-Minn human connectome project: an overview. Neurolmage 80,62-79.

Warner, C.A., Biedrzycki, M.L., Jacobs, S.S., Wisser, R.J., Caplan, J.L., and Sherrier, D.J. (2014). An optical clearing technique for plant tissues allowing deep imaging and compatible with fluorescence microscopy. Plant Physiol. 166, 1684-1687.

Yang, B., Treweek, J.B., Kulkarni, R.P., Deverman, B.E., Chen, C.K., Lubeck, E., Shah, S., Cai, L., and Gradinaru, V. (2014). Single-cell phenotyping within transparent intact tissue through whole-body clearing. Cell 158, 945-958. 